\title{
HISTORICAL REVIEWS
}

DOI 10.18524/1810-4215.2021.34.244339

\section{ASTROMETRIC RESEARCH IN UKRAINE AT THE XIX - BEGINNING OF XX CENTURIES}

\author{
Artemenko T.G. \\ Main Astronomical Observatory, National Academy of Sciences of Ukraine, \\ Kyiv, Ukraine, t.g.artemenko@ukr.net
}

\begin{abstract}
The paper presents the stages of development of astrometric research at the Ukrainian observatories in the XIX - beginning of XX century. They are related to the establishment of university astronomical observatories in Kyiv (1845), Odessa (1871), Kharkiv (1888). Mykolaiv Naval observatory was founded in 1821 for navigation needs with assistance of Admiral A.S. Greig. The absolute catalogs compiled at the Pulkovo and Mykolaiv Observatories made a significant contribution to the international work of compilation of a FK3 system.

Special attention is paid to the scientific activity of the oldest observatory at the territory of Ukraine - the Astronomical observatory of L'viv University (1771). Researches at this observatory were mainly concerned with the field of geodesy and meteorology. Despite the short first period of scientific activity (near 10 years), it gave impetus to some famous scientists. At the last decades of XIX century observatory of the L'viv University renewed their activity in astrometry, solar physics, and astrophysics.
\end{abstract}

Southern departments of Pulkovo observatory in Odessa (1899) and Mykolaiv (1912) played an important role in extension of Pulkovo absolute catalogues to the southern hemisphere. Systematic observations of the Sun conducted at these departments contributed to the more precise determination of the position of vernal equinox.

In XIX century Ukrainian observatories participated in the international programs, such as AGK (Astronomischer Gesellschaft Katalog), the photographic catalog "Carte du Ciel" (France). Among the actual observational programs were surveys of zodiacal stars (M.P. Ditchenko in Kyiv), near-pole stars (V.I. Fabritius, R.P. Fogel, M.P. Ditchenko in Kyiv, L.O. Struve K.N. and Kuz'menko in Kharkiv, I.O. Djukov, L.F.Cherniev in Odessa).In the frame of observations of Bonner Durchmusterung (BD) and its southern continuation, organized by the German Astronomical Society, observations of the equatorial zone were provided by I.E. Kortazzi at Mykolaiv observatory,
B.V.Novopashenny at the Astronomical Observatory of Odessa University in 1930s years.

Needs of astrophotography lead to the creation of the "Catalog of the faint stars" project. In 1932 at the First Astrometric Conference in Leningrad, the Pulkovo astronomers Gerasimovich B.P and Dniprovsky M.I. suggested the idea of using extragalactic nebulae as the reference objects for determination of the absolute motion of the stars. Among the tasks to be solved at the project was compilation of a general catalogue (KSZ) and a fundamental catalog of faint stars (FKSZ). It was planned to involve all the meridian instruments of the USSR as well as foreign ones, especially in the southern hemisphere. The idea of orientation of the KSZ coordinates system related to the observations of small planets was suggested by B.V. Numerov. Astronomers of Mykolaiv Astronomical Observatory participated in the international part of this project (AGK3R-catalogue).

The Poltava gravimetric observatory was founded by A.Ya Orlov in 1926 to construct a gravity map of the territory of Ukraine and to establish astrometric research, earth tides, and Latitude Service with zenith-telescopes.

The main research fields of the Main Astronomical Observatory of the NAS of Ukraine, founded by A.Ya. Orlov in 1944, were related to the positional and photographic astrometry during the first decade of its work. We defined three "genealogical scientific trees" of astrometric schools. Two of them were formed under the leadership of outstanding personalities of the XX century: Prof. Alexander Ya. Orlov (the founder and first director of the Observatory, 1944-1948, 1950-1951), who moved to Kyiv from Poltava, and Prof. Avenir A. Yakovkin (director of the Observatory in 1952-1959), who moved to Kyiv from Kazan. The third genealogical tree has grown from the Pulkovo astronomical school.

Formation of main directions of scientific researches and its transformation are also discussed.

Keywords: astrometric research, positional astrometry, photographic astrometry, fundamental astrometry. 
АНОТАЦІЯ. У статті представлені етапи розвитку астрометричних досліджень в обсерваторіях України у XIX - початку XX століття. У XIX столітті були створені університетські обсерваторії у Києві (1845), Одесі (1971), Харкові (1888). У 1921 році за сприяння адмірала О.С. Грейга була заснована Миколаївська (Морська) обсерваторія. Абсолютні каталоги, створені y Пулковській i Миколаївський обсерваторіях, зробили значний внесок в міжнародну роботу зі створення високоточного на той час фундаментального каталогу FK3.

Особливу увагу приділено науковій діяльності однієї з найперших обсерваторії на території України - Астрономічній обсерваторії Львівського університету (1771). Дослідження в обсерваторії стосувалися переважно геодезії і метеорології. Незважаючи на перший короткий період існування обсерваторії (біля 10 років), вона надала імпульс відомим науковцям. Відродження обсерваторії відбулося лише наприкінці ХІХ століття. Південні відділення Пулковської обсерваторії у Одесі (1899) i Миколаєві (1912) зіграли визначну роль у розширенні Пулковських абсолютних каталогів на південну півкулю, а систематичні спостереження Сонця, проведені у відділеннях, сприяли більш точному визначенню положення точки весняного рівнодення.

У ХІХ столітті обсерваторії України брали участь у міжнародних програмах, зокрема, таких як AGKкаталог (Німецького Астрономічного Товариства), фотографічний каталог "Карта неба" (Франція). Особлива увага приділялася актуальним спостережним програмам, зокрема спостереженняv зодіакальних зір (М.П. Диченко у Києві), біляполюсних зір (В.І. Фабриціус, Р.П. Фогель, М.П. Диченко у Києві, Л.О.Струве, К.Н. Кузьменко у Харкові, І.О. Дюков, Л.Ф., Чернієв у Одесі). В рамках спостережень за програмою Боннського огляду (BD) i його південного продовження, організованого Німецьким Астрономічним Товариством, проводилися спостереження зір екваторіальної зони (I.С. Кортацці у Миколаївській Астрономічній обсерваторії, Б.В. Новопашенний у Астрономічній обсерваторії Одеського університету).

Потреби астрофотографії сприяли розширенню фундаментальної системи зір на більш слабкі зорі, зокрема організації проекту "Каталог слабких зір". У 1932 році на Першій Астрометричній конференції в Ленінграді пулковські астрономи Б.П. Герасимович i M.I. Дніпровський висунули ідею використання позагалактичних туманностей у якості нерухомих реперів для визначення абсолютних рухів зір. Серед задач, які мали бути розв'язані у ході проекту, створення загального каталогу слабких зір (КСЗ) та фундаментального каталогу слабких зір (ФКСЗ) i встановлення зв'язку між ними. До проекту планувалося залучити всі меридіанні інструменти як СРСР, так і закордонні, особливо у південній півкулі. Ідея орієнтування координатної системи КСЗ за спостереженнями малих планет була висунута Б.В. Нумеровим. Астрономи Миколаївської астрономічної обсерваторії брали участь у міжнародній частині проекту (каталог AGK3R).

Полтавська гравіметрична обсерваторія була заснована О.Я. Орловим у 1926 році для масштабного вивчення сили тяжіння, земних припливів і для широтних спостережень.

Головні напрямки наукових досліджень Головної Астрономічної обсерваторії (ГАО НАНУ) заснованої у 1944 році стосувалися астрометрії як теоретичної, так і спостережної. Виділено і проаналізовано три "генеалогічних наукових дерева" астрометричних шкіл, два 3 яких сформувалися під керівництвом видатних постатей XX століття: професора О.Я. Орлова (засновника і першого директора обсерваторії, 1944-1948, 1950-1951), який переїхав до Києва 3 Полтави, i професора А.О. Яковкіна (директор обсерваторії у 1952-1959 роках), який переїхав до Києва 3 Казані. Третє "генеалогічне дерево" має витоки з Пулковської астрометричної школи. У статті висвітлюється формування головних напрямів наукових досліджень та їх трансформація.

Ключові слова: астрометрія, позиційна астрометрія, фотографічна астрометрія, фундаментальна астрометрія.

Scientific astronomical researches in Ukraine have begun after foundation of university observatories in L'viv (1771), Kyiv (1945), Odesa (1871), Kharkiv (1888). An important role in the development of this research played the southern departments of the Pulkovo Observatory in Odesa (1899) and Mykolaiv (1912). From the first years of their activity, the observatories were collaborated with the Pulkovo Observatory: astronomers of Ukraine worked at the Pulkovo for some time as well as the Pulkovo astronomers participated in the establishment of observatories in Ukraine (Artemenko et al., 2009; Vavilova et al., 2014).

The XIX century was the period of the international cooperative works, in particular related to the zonal catalogs AGK (Astronomischer Gesellschaft Katalog) and the photographic catalog "Carte du Ciel" (France).

The unprecedented photographic project of the XIXXX centuries - the stellar atlas Carte du Ciel was initiated practically at the same time as the Cape Photographic Durchmusterung catalog, but it was more ambitious and involved 20 observatories from around the world to expose and measure 22,000 photographic plates obtained with normal astrographs and covered the entire sky with a twofold overlap (see, review by Vavilova et al. 2020). All the measurements were also made manually using special 
procedures developed and tested with the aim to estimate possible errors and to provide the homogeneity of the resulting data. The survey, dealing with around 5 million stars (9 million images in the twofold overlap), occurred to be so laborious extending for several decades that it has never been fully completed. The results of measurements in the form of rectangular coordinates of stars and estimations of their magnitudes were published in 254 volumes in 1902-1964 as the original Astrographic Catalog (AC). Volumes of the AC were key-punched, checked, and re-reduced at the US Naval Observatory (Urban et al., 1998) and at the Sternberg Astronomical Institute in Moscow (Kuzmin et al., 1999).

In the 1930s, in order to extend the fundamental system to faint stars for the needs of astrophotography, the "Catalogue of Faint Stars" project (or KSZ) was initiated. In the 1932, at the I All-Union Astrometric Conference in Leningrad, the Pulkovo astronomers B.P. Gerasimovich and M.I. Dniprovsky suggested the idea of using extragalactic nebulae as the fixed reference points for determining the proper motions of stars. Astrometric reference to galaxies makes it possible to obtain absolute proper motions of stars and to create an almost perfect inertial coordinate system, independent on their motions in the Galaxy. The determination of zero-point (vernal equinox) for right ascensions and declinations was planned to be realized by observations of small planets.

The Kyiv University Observatory was founded in 1845 by V.F. Fedorov, a follower of V.J. Struve. Astrometric research at observatory began in 1870 s with the standing of a meridian circle made by Repsold in $1872(\mathrm{D}=122$ $\mathrm{mm}, \mathrm{F}=148 \mathrm{~cm})$. For the construction of the permanent observatory at the University for educational work the astronomical cabinet consisting mainly of expeditionary instruments by V.F. Fedorov was founded (Bogorodsky, 1995). Among the actual astrometric programs of XIX century were observations of the zodiacal zone, which were organized to provide observations of the planets by reference stars to complete the catalog of Auwers in southern zones. Activity on this program was carried out by M.P. Ditchenko ("Catalogue of positions and proper motions of 640 zodiacal stars", Ditchenko, 1933). In addition to observations of the zodiacal region of the sky, since the XIX century, astronomers made observations of stars of the near-pole zone, primarily because of 1) the lack of observations of these stars in the Auwers catalog (FC); 2) the value of systematic errors differs significantly from other zones of the sky.

In the XIX century the observations of the near-pole stars started by V.I. Fabritius on the meridian circle ( $\mathrm{D}=$ $12 \mathrm{~cm}, \mathrm{~F}=148 \mathrm{~cm})$. Since 1894 the observations were continued by R.P. Fogel. His program of observations included stars up to $9^{\mathrm{m}}$ with declinations from $+80^{\circ}$ to + $90^{\circ}$; the work continued until 1897 , but for a some reasons remained unfinished. Beginning in 1920, observations under this program were continued by M.P. Ditchenko. Observations of the occultation stars by the Moon at the observatory began in 1923 by Prof. S.D. Tscherniy. The importance of such observations explained by the fact that they provide valuable material for improving the theory of the Moon's motion, studying the figure of the Moon, determining the orientation of the fundamental reference frame, refining the scale of dynamic time. Calculations of lunar eclipses and occultation stars by the Moon, as well as their processing, were carried out by the observatory staff using both standard methods and their own developments. A.A. Yakovkin (he worked in the Kiev University Astronomical Observatory in 1945-1951) paid much attention to the development of Moon observing investigations. For computations of ephemeris, star and planet occultation, the original device constructed by Yakovkin during his work in Kazan was applied. At the suggestion of A.A. Yakovkin this device was transported by A.K. Osipov from Sverdlovsk to Kiev for calculations of occultation. The Kyiv University Observatory was the coordinator for the Moon research in the former USSR (Bogorodsky \& Chernega, 1995; M.Ya. Muminov et al. 2016).

Observatory of the Odessa University was founded in 1870-1871 by L.F. Berkevich, the first professor of astronomy in this university. The scientific activity in physics of stars was greatly recognized in the 1880s due to the efforts by A.K. Kononovich (Karetnikov (Ed.), 1994). Despite of the planned astrophysical research fields, since 1912 a systematic research on astrometry under the supervision of the director A.Ya.Orlov was started (Yatskiv et al., 2005). As he noted, "The Odessa Observatory has quite favorable climatic conditions for astronomical work. The clean air, mild climate, and a large number of transparency sky nights make it possible to conduct observations, which are not available under otherwise similar conditions for other university observatories". The first work with the Repsold Meridian Circle ( $\mathrm{D}=135 \mathrm{~mm}, \mathrm{~F}=1980 \mathrm{~mm}$ ) was to determine the positions of 125 near-polar stars by I.O. Dyukov in 19201921. This work was continuation of the near-polar stars observations conducted by M.P. Ditchenko (1898, 1933). The subsequent determination of the positions of these stars was carried out by L.F. Cherniev. Catalog of declination of 125 near-polar stars for the epoch and equinox 1950.0 (declination zone from $+80^{\circ}$ to $+90^{\circ}$ ) was compiled based on his observations (Djukov, 1923). In 1930-1935 B.V. Novopaschenny observed positions of more than 5000 stars in the equatorial zone from $+2^{\circ}$ to $-1^{\circ}$ in declination, the so called "Mykolaiv zone", earlier observed by I. Kortazzi (1900).

Since 1912, the observatory was headed by A.Ya. Orlov, who conducted studies of the Black Sea tides and deformations of the Earth. Among other his projects were restoration of the triangulation network from the Dnister river to the Dniper, leveling the Odesa coast for determining the movement of soil, development of an Ukrainian gravimetric network for mineral's search. He made a series of observations (Orloff, 1911; Orlov, 1961; Yatskiv et al. 2012) for determining the influence of the motion of the Earth's poles on the variation in the latitude of Odessa with the zenith telescope (in parallel with the similar observations in Pulkovo and Jurjew observatories).

Astronomical researches at the Kharkiv University were started in 1808 , long before the foundation of the Astronomical observatory, and related to the Levitsky's activity (Fedorov, 2002; Balyshev, 2008), who worked with the Repsold meridian circle made $(\mathrm{D}=106 \mathrm{~mm}$, 
$\mathrm{F}=1930 \mathrm{~mm}$ ). During the XIX and early XX centuries, a meridian astronomy was priority research field in this observatory. For example, observations of the zodiacal stars were carried out by L.O. Struve and N.N. Jewdokimov (1904) ("Catalogue of declinations of 779 zodiacal stars"). Also L.O. Struve conducted observations of the stars of the near-pole zone (Artemenko, 2009; Balyshev, 2021).

The result of these investigations were published later as the "Kharkov differential catalogue of declinations of 1407 circumpolar stars in the FK4 system at mean epoch 1911" (Kuzmenko et al., 1981). The observations under this program carried out by Kharkiv astronomers K.N. Kuzmenko, V.Kh. Pluzhnikov, and S.M. Grishchenko (Kuzmenko et al. 1957) were compared with the observations of 1909-1914 by L.O. Struve. A joint processing of both series of these observations was compiled in order to obtain the proper motions of stars "Katalog der Rektascensionen von Sternen des Fundamentalkatalogs schwacher Sterne im System des FK3 aus Beobachtungen am Charkover Meridiankreis in den Jahren 1953-56" (Kuzmenko, 1981; Shkuratov, 2008).

In the early XX century, a number of observatories took part in an international program of observations of the reference stars for the planet Eros in order to determine parallax of the Sun in the most accurate way for that time, and thus to establish the scale of the Solar system (parallax of the Sun corresponded to a distance of 149.6 million $\mathrm{km}$ ). Among the works in 1929-1933, in frame of this IAU program, Ostashchenko-Kudryavtsev B.P. carried out observations of 51 stars from the Kopf-Renz list, additionally included in the NFK catalog and three series of determinations of declination of large planets (observers $\mathrm{N}$. Jewdokimov, K.G. Ginze, V.A. Mikhaylov). In the field of geodesy and meteorology, the geodetic network on the left bank of Ukraine were carried out in cooperation with the Ukrainian Geodetic Instiutute (Shkuratov, 2008; Fedorov, 2002). The Kharkiv observatory carried out observations of Moon's occulations, determination of star parallaxes (M. Jewdokimov), as well as the proper motions of stars and the orbits of double stars (L. Struve). At the 1880s, L.O. Struve determined the value of the constant of precession and of the proper motion of the Solar system (Struve, 1888).

The Time Service of the Kharkiv Observatory established in 1920-1930 was one of the first in the USSR to be implemented into the International Time Service. In 1933, the first time radio signals were sent to Pulkovo in the the universal time scale, short-period irregularities in the rotation of the Earth were detected.

Mykolaiv (Naval) astronomical observatory was founded in 1821 by initiative of Admiral A.S. Greig for naval navigation needs. In the same year K.Kh. Knorre (the student of the V. Struve) arrived to Mykolaiv at Greig's initiative at the astronomer position.

In 1837 , the observatory was equipped with a meridian Reichenbakh-Ertel telescope $(\mathrm{D}=108 \mathrm{~mm}, \mathrm{~F}=1650$ $\mathrm{mm})$. It was used by the director of the observatory $\mathrm{K}$. Knorre to participate in the compilation of the catalog, the so-called "fifth sheet" of the Berlin academic star charts (from $3 \mathrm{~h} 56 \mathrm{~m}$ to $5 \mathrm{~h} 54 \mathrm{~m}$ in right ascension and from $-15^{\circ}$ to $+15^{\circ}$ in declination) (Pinigin \& Eral, 2009).

The first "big datasets" of astronomical objects were obtained as result of visual observations. The beginning was laid by F. Argelander with his Bonner Durchmusterung (BD, 1859-1862) survey of stars down to about visual magnitude $9^{\mathrm{m}}-10^{\mathrm{m}}$. The BD firstly contained 324,188 stars from the North celestial pole to $2 \circ$ South of the celestial equator. In 1886 the BD was enhanced with Sudliche Bonner Durch musterung (SBD) down to $-23^{\circ}$. The SBD added about 138,000 stars observed with a 6-inch Bonn refractor using the same technique as the BD. It was also supplemented with two surveys made at observatories located in the Southern hemisphere. The first one was the Cordoba Durchmusterung (CD, 1892-1932) covering the Southern stars in declination zones from $-22^{\circ}$ to $-89^{\circ}$. The Mykolaiv Observatory participated in the observations of the Bonner Durchmusterung and its southern continuation, organized by the German Astronomical Society. During 1872-1899 I.E. Kortazzi carried out observations of 5954 stars in the zone of declination $-2^{\circ} 10^{\prime} \div+1^{\circ} 10^{\prime}$ ("Mykolaev zone"). Since 1912 Mykolaiv observatory continued its activity as a Southern department of Pulkovo observatory (Pinigin, 1998; Pinigin \&Pozhalova, 2011).

The purpose of the southern departments of the Pulkovo Observatory - in Odessa (1899) and Mykolaiv (1912) was extension of the Pulkovo absolute catalogs of stars to the southern sky, namely to $-30^{\circ}$ in declination, to clarify the position of the point of the vernal equinox and for Sun's observation.

The first work at the Odessa department of Pulkovo observatory was conducted in 1901-1902 by B.P. Ostashchenko-Koudriawtzev, namely observations for the catalog of declination of 407 stars and 202 stars in the zone of declination from $-15^{\circ}$ to $-30^{\circ}$ (continuation of the Pulkovo catalog of 1900). The next program was the compilation of the catalog of 199 stars as the continuation of the Pulkovo catalog 1905 to the southern sky to the declination $-30^{\circ}$ (1904-1907).

In 1912 the department was transferred to Mykolaiv. The first observers in Mykolaiv were the Pulkovo astronomers P.I. Yashnov, M.V. Zimmerman, and B.P. Ostashchenko-Koudriawtzev.

The absence of cloudy weather in Mykolaiv gives advantages to Mykolaev, especially during daytime observations with meridian instruments. A FreybergKondratyev passage instrument $(\mathrm{D}=108 \mathrm{~mm} \mathrm{~F}=1300$ $\mathrm{mm})$ and a Repsold vertical circle $(\mathrm{D}=108 \mathrm{~mm} \mathrm{~F}=1400$ $\mathrm{mm}$ ) were transported to Mykolaiv from Odessa. The Mykolaiv department in cooperation with the Pulkovo Observatory participated in observations of stars for the compilation of the fundamental catalog for "Carte du Ciel" (Bucklund-Hof stars). Meridian observations for this program were carried out at 10 observatories in both hemispheres. Most of these observations north of $10^{\circ}$ were combined in two catalogs - right ascension catalog compiled at Pulkovo by F.F. Renz, and the declination catalog, compiled at the Astronomical Institute by M.I. Dneprovsky. In 1928, the Pulkovo Observatory began the meridian observations to refine the positions of the FK, where the Mykolaiv Observatory made observations from the pole to $-30^{\circ}$ (Pinigin \& Pozhalova, 2011).

The absolute catalogs of 1930 created by the Pulkovo and Mykolaiv Observatories according to V.Ya. Struve 
plan made a significant contribution to the international work on the high-precision fundamental system FK3. Nine absolute Pulkovo and Mykolaiv catalogs of 1915, 1925, and 1930 were used at the FK3 compilation (Mikhailov et al., 1960).

The observatory participated in observations under the program of observations of "1334 geodetic stars" (principal investigator, the Pulkovo astrometrist M.V. Zimmerman). This program was organized because of by the lack of sufficient number of 5-6 magnitude stars important for time and geodesy services in catalogs of F.F. Renz and M.I. Dneprovsky. Five observatories took part in observations from 1933 till 1938. Total processing of obtained observations and their integration with the Pulkovo catalog 1925 was completed in 1941.

Established in 1931, the time service of Mykolaiv Observatory participated in the all-Union and international programs for determination the time. There was established a regular reception of radio signals to the exact time of the Soviet and foreign radio stations. Since 1949 the Mykolaiv Time Service was equipped with new timekeeping devices became a part of the USSR uniform time services system (Pinigin, 1998).

The problem of studying the rotation of the Earth and the motion of the poles was developed with the foundation of the Poltava Gravimetric Observatory (1926). The importance of studying the motion of the Earth's poles caused by the fact that their movement causes changes in the geographic coordinates, azimuths of points and affects the results of the exact time. In the late 1940s, the founder of the Poltava Observatory, A.Ya. Orlov, proposed to study the slow variations in latitude and the nutation motion of the Earth's axis (Yatskiv et al. 2005, 2012).

The International Latitude Service, which had already been working for half a century at that time, could not solve this problem due to deficiencies in its organization. There was a need for a fundamentally new program, built on new principles to study not only the periodic, but also the secular motion of the pole. Such a program was developed in the late 1940s at the Poltava Observatory by E.P. Fedorov. The main purpose of observations was to study the slow variations in mean latitude and the secular motion of the pole. It was also supposed to study the nutation movements of the Earth's axis, to obtain the data on periodic variations in latitude for calculating the coordinates of the pole, and to study the nature of nonpolar variations in latitude. Several Soviet and foreign observatories have been involved in this "Poltava program". To study the motion of the Earth's poles in the Poltava Gravimetric Observatory, the parallel observations with three zenith telescopes were conducted: Zeiss $(\mathrm{D}=135 \mathrm{~mm} \mathrm{~F}=1760 \mathrm{~mm})$, Bamberg $(\mathrm{D}=110$ $\mathrm{mm}, \mathrm{F}=1230 \mathrm{~mm}$ ) and ZTM-180 (domestic production, $\mathrm{D}=180 \mathrm{~mm}, \mathrm{~F}=2340 \mathrm{~mm}$ ).

The question to establish a new astronomical observatory in the system of the Academy of Sciences of UkrSSR was a "great dream" by A.Ya. Orlov since 1920s. It was realized: the Main Astronomical Observatory of the AS UkrSSR (MAO) was found in 1944 in Kyiv, and A.Ya. Orlov became the director. Among the first research fields of the observatory were positional astronomy (astrometry and the study of the rotation of the Earth) and photographic astrometry (Yatskiv, 2019). In this content, M.F. Subbotin, a well-known expert in celestial mechanics, recommended to make observations of large and small Solar system planets with the photographic instruments. In his opinion, it should be helpful for the creation of the Catalogue of Faint Stars to correct the positions of the zero-point coordinate system.

During 1945-1946 the Observatory obtained the first instruments: a double short-focus astrograph $(\mathrm{D}=12 \mathrm{~cm}$, $\mathrm{F}=70 \mathrm{~cm}$ ) made by N.G. Ponomaryov, a vertical Vanshaff circle $(\mathrm{D}=19 \mathrm{~cm}, \mathrm{~F}=252 \mathrm{~cm})$, a double longfocus astrograph $(\mathrm{D}=40 \mathrm{~cm}, \mathrm{~F}=550 \mathrm{~cm})$ made by Tepfer. According to the final report of the observatory for the first five years of activity, the following tasks were carried out: for the creation of the Catalog of faint stars: setting up of $40 \mathrm{~cm}$ astrograph and vertical circle, photographing galaxies in order to have positions of faint stars in distant objects, determination of declination of stars; and a complete study of the vertical circle.

Among the main research fields during the first decades were named astrometry and global geodynamics (studies of latitude variations and pole movements; astronomical constants, in particular nutation; classical astrometry compilation of stellar catalogs according to the latitude program as well as a catalog of faint stars). The development of fundamental and photographic astrometry at the MAO has begun under the head of the representatives of the Pulkovo astrometric school. Thus, the founder of photographic astrometry at the MAO, I.G. Kolchinsky, completed his postgraduate studies under the A. Tikhov supervision. After setting up the instruments, he began work on photographing small planets and galaxies (as a part of the "Catalogue of Faint Stars" with A.B. Onegina (who completed her graduate studies under the Pulkovo astrometrist A.N. Deich supervision) and I.V. Gavrilov. Among other works related to I. Kolchinsky, we note studies of astronomical refraction anomalies. Later, the photographic astrometry projects were expanded (FON catalogues) as well as the archives of observations were digitized in frame of the Ukrainian Virtual Observatory (Vavilova et al., 2017). At the end of 1940, an outstanding astrometrist A.A. Yakovkin established yet one research field at the MAO: fundamental astrometry and the study of the Moon (Kislyuk et al., 1996).

Scientific research at the Observatory of L'viv University, the oldest at the territory of modern Ukraine, were initiated by Rector D. Zelyonka at 1771 and mainly related to geodetic works, in particular the mapping of Galicia and Volyn' territories. Although the observatory existed a little more than 10 years, during this time it become an authority scientific organization, giving impetus to scientific activity for such scientists as F. von Tsakh and S. Serakovsky (Novosyadlyi, 2011).

The new stage of development of astronomy in L'viv in the late XIX century is associated with the development of astronomical observatory at the L'viv Polytechnic University. At the beginning of the $\mathrm{XX}$ century the seismographic station began to work. And already in 1918 it was equipped with three basic astronomical instruments: a passage instrument (Troughton and Simms), a refractor with $122 \mathrm{~mm}$ objective (Fraunhofer and Ressel), the Ertel instrument with $81 \mathrm{~mm}$ objective. In addition to these 
instruments, the observatory had several astronomical pendulum clocks, chronometers. Oservations of Sun and Moon eclipses, the passage of Mercury across the Sun's disk were observed. The results of the observations were mainly published in the Astronomische Nachrichten journal.

At the end of the XIX century the Department of Astronomy at the L'viv University was founded. The main works were related to the observations of planets and comets, determination of latitude by the Talcott method, observations of eclipses, occultation stars by the Moon, variable stars, meteors, new stars, and the passage of Mercury across the solar disk. Headed by Prof M. Ernst, the observatory was equipped by Mertz refractor $(D=134$ $\mathrm{mm}, \mathrm{F}=180 \mathrm{~cm}$ ), a universal instrument, a pendulum clock, a solar chronometer, as well as a number of small laboratory instruments were acquired. The subject of astronomical research extended significantly in 1932, when E. Ribka was appointed at a director's position. The observatory was enlarged with new instruments: star and solar chronometers, a camera with a Zeiss triplet lens $(\mathrm{D}=$ $100 \mathrm{~mm}, F=50 \mathrm{~cm}$ ), pavilions for Mertz refractor, astrocamera $(D=140 \mathrm{~mm}, F=70 \mathrm{~cm}$ ) and for Zeiss refractor $(\mathrm{D}=130 \mathrm{~mm}, \mathrm{~F}=240 \mathrm{~cm})$ were bought. From 1939, studies of variable stars, photographic and stellar photometry, as well as on celestial mechanics and solar physics were significantly expanded (Novosyadlyj, 2011).

\section{References}

Artemenko T.G., Balyshev M.A., Vavilova I.B. (2009). Kinemat. Phys. Celest. Bodies, 25, 153. doi: 10.3103/S0884591309030040

Artemenko T.G. (2009). Astronomical School's Report, 6, 187. doi:10.18372/2411-6602.06.2187

Balyshev M.A. (2008). In: 200 Years of Astronomy at the University of Kharkiv. Kharkiv, Karazin Kharkiv University, 2008. p. 99-154.

Balyshev M. (2021). Kinemat. Phys. Celestial Bodies, 37, 269. doi: 10.3103/S0884591321050032

Bogorodsky A.F., Chernega M.Ya. (1995). Astronomical Observatory of Kyiv Taras Shevchenko University. 150 years. PH Kyiv University, p. 13-121.

Ditchenko M. (1898). Bulletin de l'Acad. Imp. des sciences de St. Petersbourg, V serie, 9, No.3, 215.

Ditchenko M. (1933). Catalogue de 640 etoiles zodiacales. Ann. de l'Obs. de Kiew, 6, 1.

Djukov J. (1923). Astron. Nachr., 219, Nr. 5250), 285.

Fedorov P.N. (2002). Bulletin of Astronomical School. 3, No. 2, 42.

Karetnikov V.G. (1994). Pages of the history of astronomy in Odessa: a collection of papers. Odessa, Astroprint, 1994, Vol. 1, 112 p.

Kislyuk V.S., Shkuratov Y.G., Yatskiv Y.S. (1996). Kosm. nauka tehnol.; 2, 3. doi: 10.15407/knit1996.01.003

Korsun A.A., Yatskiv Y.S. (1994). In: Pages of history of creation and establishment of the Main Astronomical Observatory of of the NAS of Ukraine. Kyiv, MAO NASU, 1994 pp. 8-19.

Kortazzi I. (1900). AGK1 catalog, $-2^{\circ} 10^{\prime} \leq \mathrm{DE} \leq 1^{\circ} 10^{\prime}$. VizieR Online Data Catalog, 2007.
Kuzmenko K.N., Kirpatovskij V.M., Pavlenko L.S. (1981). Kharkov differential catalogue of declinations of 1407 circumpolar stars in the FK4 system at mean epoch 1911 (Manuscript).

Kuzmenko K.N., Pluzhnikov V.K. (1957). Publ. Astr. Obs. Charkov, 13, 19.

Kuzmin, A., et al. (1999). Astron.\& Astrophys. Suppl. Ser., 136, 491. doi: doi.org/10.151/aas:1999229.

Mikhailov A.A., Zverev M.S., Kulikovskii P.G. et al. (1960). Forty Years of Astronomy in the USSR, 19171957. Vol. 2. Bibliography. Moscow, Fizmatgiz, 602 p.

Muminov M.M., Kazantseva L.V., Ehgamberdiev S.A. et al. (2016). Izvestiya Glavnoj Astronomicheskoj Observatorii v Pulkove, 223, 333.

Novosyadlyj B.I. Ed. (2011). History of the Astronomical Observatory of the Ivan Franko National University of L'viv. L'viv, LNU, 240 p.

Orloff, A. (1911). Publikationen der Kaiserlichen Universitaets-Sternwarte Jurjew, 21, B29-B34.

Orlov A.Ya. (1961). Selected works: in 3 volumes. Ed. Aksentyeva Z.N., Kyiv, Publishing house of the Academy of Sciences of the Ukrainian SSR.

Pinigin G.I. (1998), Ed. Nikolaev Astronomical Observatory. A Star Path of 175 Years. Nikolaev, Atoll.

Pinigin G.I., Eral S.F. (2009). The Dynasty of Knorre Astronomers, Nikolaev, Nikolaev: Irina Gudym Publishing House, 2009, 148 p.

Pinigin G.I., Pozhalova J.A. (2011). Nikolaev Observatory in the first half of XX century. Nikolaev: PH Irina Gudym, 2011, 148 p.

Shkuratov Yu.G. (Ed.) 200 years of astronomy at the Kharkiv University" (2008). Karazin Kharkiv National University, 632 p. ISBN 978-966-623-473-.

Struve L. (1888). Mémoires de VAcadémie Impériale des Sciences de St.-Pétersboui'g, viie série, t. Xxxv, no. 3 (MNRAS, 1889, 49, 220)

Struve L., Jewdokimow N. (1904). Annales de l'Obs. Astron. de l'Universite Imperiale de Kharkow, Tome I, 158.

Urban S.E. et al. (1998). Astron. J., 115 (3), 1212. doi: $10.1086 / 300264$.

Vavilova I.B., Artemenko T.G., Pakuliak L.K. (2014). Kinemat. Phys. Celest. Bodies, 30, 46. doi: 10.3103/S0884591314010073

Vavilova I.B., Yatskiv Ya.S., Pakuliak L.K. et al. (2017). Proceedings IAU Symp. Astroinformatics, 325, 361. doi: $10.1017 /$ S1743921317001661

Vavilova I., Pakuliak L., Babyk I. et al. (2020). In: Knowledge Discovery in Big Data from Astronomy and Earth Observation, 57-102. doi:10.1016/B978-012-819154-5.00015-1

Yatskiv Ya.S., Korsun A.O., Vavilova I.B. (2005). Kinemat. Fiz. Nebesnykh Tel, 21, 403.

Yatskiv Ya.S.; Vavilova I.B.; Korsun' A.A. (2012). Odessa Astronomical Publications, 25, 74.

Yatskiv Ya.S., Ed. (2019). Korsun A.O., Kryachko I.P. (Comps.). Main Astronomical Observatory of the NAS of Ukraine: from idea of establishment to the international recognition. Kyiv: Nauk. Dumka, 415 p. 